\title{
De la Ligereza
}

\author{
Dr. Braulio Angulo Arjona \\ Doctorante. Giséle Angulo Noriega \\ Dra. María Guadalupe Noriega Aguilar
}

De la ligereza. Hacia una civilización de lo ligero es un libro escrito por Gilles Lipovetsky, filósofo francés que actualmente se erige como autoridad en el análisis de la dinámica de la sociedad mundial, y es precisamente en este libro, que plasma sus planteamientos más controversiales sobre la dinámica social actual y sus consecuencias. Él afirma que la ligereza es la tendencia dominante en el espíritu de nuestra época. Y profundiza diciendo que Jamás habíamos vivido en un mundo material tan ligero, fluido y móvil, que Nunca había creado la ligereza tantas expectativas, deseos y obsesiones. Nunca había hecho comprar y vender tanto. Nunca había sonado tan justo en nuestros oídos aquello que dijo Nietzsche: <Lo bueno es ligero, todo lo divino camina con pies delicados> y a continuación afirma: la ligereza es un valor, un ideal, un imperativo, estamos en la civilización de lo ligero. Ahonda diciendo; la ligereza era un ideal estilístico o un vicio moral. Hoy es una dinámica global, un paradigma transversal, un <hecho social total> cargado de valor tecnológico y económico, funcional y psicológico, estético y existencial. Hoy proliferan los dominios que expresan el combate de lo ligero contra lo pesado.

En el terreno de la vida personal señala que la primera modernidad era pesada, moralista y rigorista; buscaba compromisos e imponía obligaciones. La última modernidad ha desencadenado una revolución liberadora que sin embargo presenta una doble cara. Por un lado se caracteriza por la búsqueda y el cultivo de la libertad individual, la comodidad, la indiferencia, lo cool, la relajación interior, pero por otro tiene contrapartidas peligrosas. Los individuos necesitan sentirse libres, pero también quieren establecer vínculos. El resultado de esta tensión es una angustia que no cesa. Tampoco cesan, antes bien crecen, la incultura de los estudiantes, las agresiones y falta de respeto cotidiana, la desinformación de los medios de información, la inmoralidad de los representantes públicos, el número de suicidios, los neofascismos disfrazados de progresismos, la distancia económica entre pobres y ricos, y advierte: estamos sólo en los comienzos.

Profundiza citando a Nietzsche: él vinculaba el <espíritu de la pesadez> a la carga de la trascendencia de los trasmundos, a los ideales de la religión, la moral el Estado, que impedían al hombre vivir con ligereza.
$Y$ reafirma que con el modelo de la hipermodernidad se ha disipado la fuerza apremiante de los grandes valores idealistas, pero confirma que ni aún con esto, el espíritu de la pesadez ha desaparecido, dado que continúa con la forma del autodesprecio, la depresión y la ansiedad, y puntualiza, en realidad, que nuestra época apenas ha avanzado en la dirección de la vida ligera, si es que ésta significa como quería Nietzsche, <amarse a uno mismo> porque la vida es todavía muy pesada de sobrellevar. Lo notable es que sea una cultura de la ligereza lo que contribuya a cambiar el rumbo del nihilismo del >espíritu de la pesadez> La pesadez no proviene ya del mundo suprasensible, sino de las normas de una cultura narcisista que debe favorecer la ligereza.

Y enfatiza, el autor francés, la paradoja que esto implica, con esta frase: Las llamadas insistentes a la ligereza obran ya contra la ligereza de vivir.

Lo ligero aparece como el emblema 0 la tonalidad dominante del mundo de las economías de consumo, que se caracterizan por estar inmersos en la creencia de que: "una vida sin placer ya no es una verdadera vida: vivir sin ligereza consumista se ha vuelto sinónimo de vida aburrida y desperdiciada especifica que aunque es necesario criticar el consumismo invasivo, no se critica su presunta pesadez, sino el hecho de que no basta para realizar plenamente una vida. Una vida humana digna de este hombre que no sabría llegar a esta dimensión si no faltaran los demás horizontes de la existencia. La ligereza consumista no es indigna: es humanamente pobre cuando pasa a ser regla de conducta preponderante y omnipresente.

Concluye enfatizando que: la verdad es que lo más pesado no es la futilidad consumista, sino la pobreza real, la angustia de no tener suficiente y tener que pagar siempre, la eliminación de toda frivolidad, la falta de horizontes y de futuro. $Y$ añadamos además que lo más pesado no se encuentra tanto en la ligereza del kitsch comercial como en los conflictos intersubjetivos, en las insatisfacciones del mundo laboral, en las heridas subjetivas.

Al análisis del filósofo de cómo la ligereza va permeando todos los ámbitos especialmente el consumo, no escapan aspectos que han sido impactados como: 
El cuerpo, por lo que comenta: "pues el ideal de ligereza se acompaña de normas exigentes de efecto agotador y a veces deprimente: tener un cuerpo esbelto supone muy a menudo la renuncia a la tranquilidad del carpe diem, una existencia en los antípodas de la vida despreocupada.

El arte del que dice: no ha sido nunca un entretenimiento puro; como expresión de los significados religiosos y sociales más elevados y como portador de los máximos valores de la cultura, el arte ha desempeñado un papel mayor en el orden imaginario y simbólico de las sociedades. Esta situación del arte es históricamente inédita. En las obras de arte (actual) encontramos en el mejor de los casos, alguna cosa, interesante. Una de las expresiones favoritas de los visitantes de exposiciones es ésta, "es interesante" ¿Qué significa esta fórmula sino un interés inconcreto, vago, poco profundo? Edgar Wind asegura acertadamente que una obra considerada "interesante" despierta un interés que decrece muy de prisa: corresponde a una curiosidad volátil, sin profundidad ni efecto duradero.

La ligereza designaba una cualidad de las obras; hoy describe la relación que tenemos con ellas: una relación de consumidores inconstantes, ávidos de novedades por el placer de entretenernos.

El sexo y amor, especial atención les dedica en esta obra, explicando que aunque la sexualidad se ha vuelto una preocupación omnipresente, hay que señalar que no vivimos en modo alguno en una época entregada a la anarquía libidinal. Se nos pinta una sociedad dominada por una especie de libertinaje en masa: la verdad es que éste no se ve por ninguna parte.

La sexualidad cool se ha vuelto legítima, pero en realidad se vive muy poco como tal, dado que en este campo andan por medio la cuestión de la propia imagen y la fuerza de los sentimientos y aunque las prácticas sexuales sean más recreativas, las relaciones en cuanto tales no se parecen al zapeo del consumidor. El valor que se concede al amor y a la proximidad, la necesidad de seguridad legítima, el deseo de no ser considerado un objeto intercambiable frena continuamente la trashumancia del deseo y mantienen el principio de la ligereza dentro de unos límites relativamente firmes. ¿Cómo se explica la moderación? Cuestiona; señalando a continuación: lo ligero tiene dos filos, pues la libertad individualista, por poner fin a los vínculos indestructibles trae consigo la sensación de inseguridad, de incertidumbre sobre el futuro, de miedo a la <expulsión>. La fragilidad de los lazos y la facilidad actual para las desvinculaciones traen consigo unas veces las delicias de la renovación, otras la pesadilla de quedar colgados, abandonados, solos. Todo se ha vuelto temporal, flexible, desechable: un proceso de desvinculación con su inevitable cortejo de heridas, llantos, decepciones, sensaciones de fracaso doloroso y no piensan sino en protegerse de sufrimientos que siempre son posibles en las relaciones afectivas. La soledad como consuelo: más vale estar solo que vivir conflictos agotadores y un nuevo fracaso. La libertad en materia de relaciones se transforma en miedo a las relaciones.

Confirma en el análisis de este punto: Son los códigos del sentimiento y de la comunicación intimista los que frenan, no sin éxito, las correrías del deseo, funciona al mismo tiempo como vehículo de intensificación del deseo, funciona al mismo tiempo como vehículo de limitación y fijación de Eros. El amor, al menos cuando es correspondido, aligera la sensación de vivir, pero impide tomarse el sexo <a la ligera>

Y si el amor sigue recibiendo tan encendidos elogios es porque responde a uno de los deseos más profundos del individuo: ser reconocido como persona singular.

Otros temas que toca con la fuerza de su análisis son la feminidad, la arquitectura y el diseño, la nanotecnología, la moda y la libertad. De tal manera que Roger-Pol Droit, del diario francés Le Monde, dice: "Lipovetsky, sostiene con su fuerza habitual, que lo ligero no es un fenómeno de moda ni un efecto de superficie. Es un hecho social total. Hablar de "civilización de lo ligero" se ha vuelto hoy legítimo. Y Gilles Lipovetsky lo hace magistralmente.

\section{SEMBLANZA DE AUTORES:}

Braulio Angulo Arjona, Giséle Angulo Noriega, María Guadalupe Noriega Aguilar, profesores investigadores de las Divisiones Académicas de Educación y Artes e Ingeniería y Arquitectura de la Universidad Juárez Autónoma de Tabasco, México.

\section{REFERENCIA BIBLIOGRAFÍCA:}

Lipovetsky, Gilles (2016). De la ligereza. Barcelona España: Editorial Anagrama. 